\title{
The influence of the trematode Microphallus claviformis on two congeneric intermediate host species (Corophium): infection characteristics and host survival
}

\author{
Tomas Jensen*, K. Thomas Jensen, Kim N. Mouritsen \\ Department of Marine Ecology, Institute of Biological Sciences, University of Aarhus, Finlandsgade 14, \\ DK-8200 Aarhus N, Denmark
}

Received 8 April 1997; received in revised form 8 November 1997; accepted 17 November 1997

\begin{abstract}
In a laboratory experiment the survival of two amphipod species Corophium volutator and $C$. arenarium was differentially affected by the digenetic trematode Microphallus claviformis, the former suffering from parasite induced mortality. No clear species specific parasite preference was observed, but there was a difference between the two frequency distributions of parasite number per host, indicating a preference for the competitively superior $C$. volutator. In both species the parasite metapopulation was overdispersed, but to the highest degree in C. volutator. Formation of a penetration cyst on the Corophium cuticle preceeds the penetration of the M. claviformis cercariae, a common feature of microphallid digeneans, but not earlier reported from this species. Dead individuals of both species carried significantly more penetration cysts than the live ones which suggests that massive invasion of cercariae during a short period of time is the cause of death of Corophium, rather than crude parasite intensity. The potential for $M$. claviformis to act as a structuring agent in communities of Corophium species is discussed. (C) 1998 Elsevier Science B.V.
\end{abstract}

Keywords: Corophium; Hydrobia; Parasites; Microphallus; Mortality; Trematodes

\section{Introduction}

The two congeneric species Corophium volutator (Pallas) and C. arenarium Crawford (Crustacea: Amphipoda) are often very abundant inhabitants of intertidal mudflats along the north-western European coasts. Generally, the two species show a distributional pattern where $C$. volutator inhabits the more silty substrata and $C$. arenarium the coarser

*Corresponding author. Tel.: + 458942 4395; fax: + 458942 4387; e-mail: toje@ bio.aau.dk 
ones (Watkin, 1941; Jensen and Kristensen, 1990; Beukema and Flach, 1995). However, the two Corophium species also occur sympatrically at several locations (Flach, 1993; Jensen, 1996). As $C$. volutator is a superior competitor to $C$. arenarium, their coexistence may be mediated through selective impact of other organisms, and bird predation has been suggested to play this role (Jensen and Kristensen, 1990). However, other more subtle biotic interactions, such as parasitism, could also be important as a structuring force (Dobson and Hudson, 1986; Price et al., 1986; Scott and Dobson, 1989; Minchella and Scott, 1991; Esch and Fernández, 1993). In intertidal softbottom communities digenetic trematodes are the dominant macroparasites (Sousa, 1991), and several of these are known to utilize Corophium as second intermediate hosts. Furthermore, populations of Corophium have long been known to exhibit largely unexplained spatial and temporal fluctuations in density (Watkin, 1941; Muus, 1967; Reise, 1978; Ólafsson and Persson, 1986; Lauckner, 1987; Bick, 1994; Beukema and Flach, 1995), and population breakdowns have been reported. In at least one case an epizootic caused by digenetic microphallid trematodes has been reported from a population of $C$. volutator (Jensen and Mouritsen, 1992). In addition, Mouritsen and Jensen (1997) have shown that the digenetic trematode Maritrema subdolum is capable of inflicting additive mortality on $C$. volutator under laboratory conditions in a highly temperature dependent manner.

The aim of the present experimental study is to investigate the infection mode of the digenetic microphallid trematode Microphallus claviformis and its impact on survival of the two congeneric Corophium species. This parasite utilizes Hydrobia species as first and Corophium as second intermediate host in its life cycle. The adult trematode lives in the digestive tract of various birds to which it is transmitted via their predation on infected Corophium. The possible consequences of parasitism for coexistence between these two congeneric intermediate host organisms are evaluated and discussed.

\section{Materials and methods}

Specimens of $C$. volutator and $C$. arenarium were collected in September 1995 on intertidal flats near Højer, Denmark (545'스, $8^{\circ} 38^{\prime} \mathrm{E}$ ), $400 \mathrm{~m}$ from the mean high water level, using a $500 \mu \mathrm{m}$ mesh sieve. Specimens of Hydrobia ulvae (Pennant) were collected during spring and summer 1995, along the entire range of the intertidal flat, using a $1000 \mu \mathrm{m}$ mesh sieve. In the laboratory, Hydrobia snails were inspected for cercariae shedding in a small water body. Cercariae were identified to species according to Deblock (1980), using a light microscope. Until the beginning of the experiment, infected Hydrobia snails were stored in containers with sediment rich on diatoms and a sea water level of $2 \mathrm{~cm}$. The containers were positioned under light at $15^{\circ} \mathrm{C}$ in order to promote diatom growth. The water and sediment were renewed at monthly intervals.

Specimens of Corophium were transported to the Roenbjerg Marine Biological Laboratory and established in aquaria with running sea water (approx. $25 \%$ o, $15^{\circ} \mathrm{C}$ ), constant air flow and a layer of diatom rich sediment $(<500 \mu \mathrm{m})$ as a food source. Animals used in the experiment were individually picked from the batch by suction with 
a glass pipette and inspected under a binocular microscope for species determination according to Lincoln (1979).

The mean lengths ( $\pm \mathrm{SD}$; rostrum-telson) of $C$. arenarium and $C$. volutator (measured post-experimentally) were $4.5 \pm 0.41 \mathrm{~mm}(N=163)$ and $4.5 \pm 0.52 \mathrm{~mm}(N=139)$ respectively, and no differences between the size distributions of the two experimental populations were found (Kolmogorov-Smirnov, $P>0.05$ ). Both groups showed a sex ratio not significantly different from 1:1 (Chi-square tests with Yates' correction, $P>0.05)$.

The experiment was performed at $24 \pm 1^{\circ} \mathrm{C}$, a temperature that previously has ensured a substantial transmission of microphallid cercariae between hosts of Hydrobia and Corophium (Mouritsen and Jensen, 1997). During the experiment the animals were exposed to artificial light only. The experimental aquaria (Fig. 1) consisted of glass jars $(0.51)$ each supplied with sieved defaunated sediment $(<500 \mu \mathrm{m})$ to a height of $5 \mathrm{~cm}$ and a sea water level of additional $3.5 \mathrm{~cm}$ (25\%o). They were left to acclimate to the experimental conditions for 2 days with constant air supply before the start of the experiment. To prevent oxygen depletion during the experiment, air was automatically supplied for 15 min every hour.

At the start of the experiment, 30 Corophium individuals and 10 infected Hydrobia snails were added to each jar, corresponding to 6000 and 2000 individuals $\mathrm{m}^{-2}$ respectively. To prevent the snails from surfacing, they were placed in small submerged net containers (mesh size $500 \mu \mathrm{m}$ ) positioned in the substratum in the centre of each aquarium (Fig. 1). With six replicates of both treatment and control aquaria for each species of Corophium a total of 24 aquaria was established. To the treatment aquaria, 10 $M$. claviformis infected snails were added. The preferred use of uninfected snails in the control aquaria is difficult to achieve due to the inadequate use of cercariae shedding to

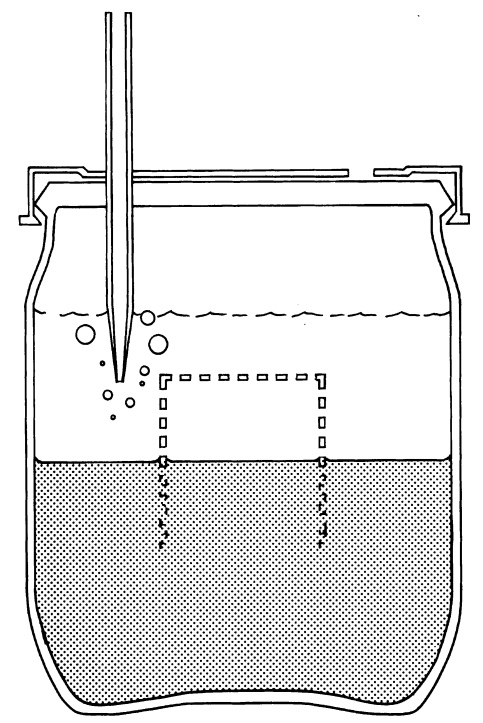

Fig. 1. Experimental aquaria consisting of a 0.51 glass jar, closed with a lid to prevent evaporation. 
determine whether a snail is infected or not (Curtis and Hubbard, 1990). Instead, the control aquaria were supplied with Himasthla infected Hydrobia (Mouritsen and Jensen, 1997). Himasthla, also being digenetic trematodes, utilize various bivalves as their second intermediate hosts. Interspecific double infections are very rare among Hydrobia snails from the locality of collection (pers. obs.).

The duration of the experiment was 11 days. During this period, the aquaria were inspected daily, and encountered dead Corophium preserved in $4 \% \mathrm{pH}$-buffered formaldehyde in sea water. The number of surface active individuals in each aquaria was counted daily. A Corophium was only designated surface active, if the entire animal had left its burrow. The positions of the aquaria, arranged in a block formation, were changed at random four times during the experiment, to rule out spurious gradient effects. Furthermore, $20 \mathrm{ml}$ of diatom rich sediment were added twice during the experiment. Evaporated water was compensated for by addition of distilled water once during the experiment.

After the experiment, all Corophium specimens from the treatment aquaria and a representative number from the control aquaria were dissected using a binocular microscope. The entire body and appendages were mounted on a glass slide using glycerine gelatine. Specimens that died during the experiment, but were preserved in a suitable condition, were treated in a similar way. Intensity of infections obtained pre-experimentally in situ as well as during the experiment was determined using a Zeiss Differential Interference Contrast (DIC) Microscope. New experimental infections were dinstinguished from older pre-experimental metacercariae by differences in size and morphology, and so were metacercariae of different species obtained pre-experimentally in situ (own data, in prep.).

All batches of $M$. claviformis infected snails were checked for shedding of cercariae immediately after the termination of the experiment.

Statistical analyses were performed using the statistical package SPSS for Windows (release 6.1.3). Prior to the parametric tests, data were examined for violation of assumptions, and, if so, transformed or a non-parametric test applied instead. Before analyses of surface activity at day 1 and 11, the percentage data were normalised by the arcsine transformation. Zero proportions were counted as $1 /(4 N)$, according to Snedecor and Cochran (1989). All tests were two-tailed and used the 5\% level of significance.

\section{Results}

\subsection{Mode of infection}

After the cercariae of M. claviformis (Fig. 2A) have established physical contact with Corophium, and somehow adhered to its surface, they perform leech-like movements on the host surface until they reach a suitable site for penetration. When a cercaria has done so, it first shortens and thickens, then the tail detaches and finally a mucous layer is secreted around the cercaria, shielding off the external environment. The duration of this process is a few seconds, and it can be induced on a microscope slide as well, by a cautious tapping on the cover slip (Fig. 2B). The mucous layer quickly stiffens, forming 

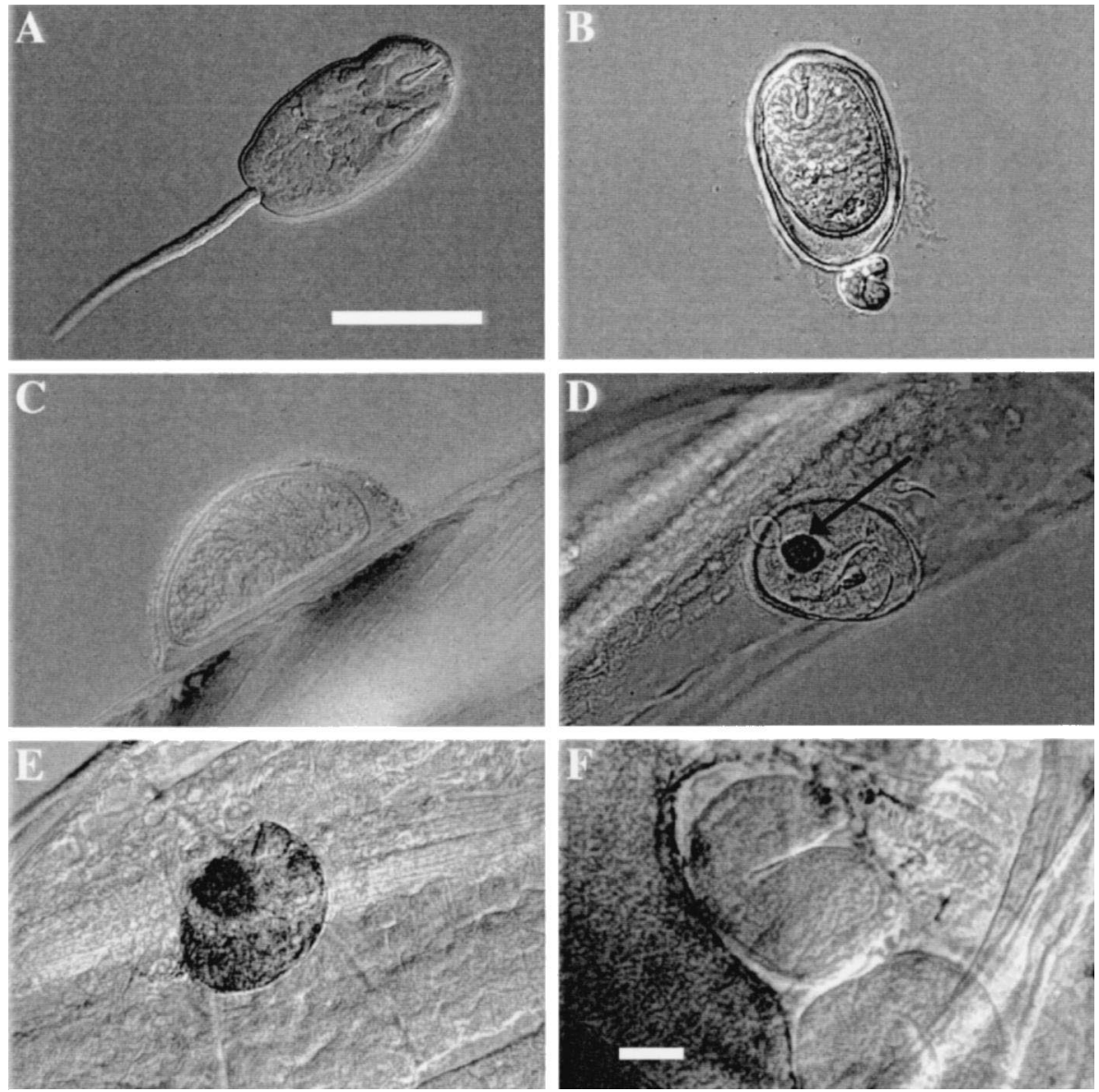

Fig. 2. Microscope photographs showing (A): The cercariae of Microphallus claviformis ; (B): Artificially induced formation of a penetration cyst; (C): Cercaria penetrating Corophium cuticle from its penetration cyst; (D): Empty penetration cyst on a Corophium limb, arrow indicates the penetration hole; (E): Immobilized or dead cercaria surrounded by red (dark) substances; (F): New metacercariae in initial phases of encystment within a Corophium specimen. Scale bars on A (holds for B-E also) and F indicates 100 and $50 \mu \mathrm{m}$ respectively.

a rigid cyst - the penetration cyst. From the penetration cysts the cercariae make their way through the Corophium cuticle to the hosts' haemocoel (Fig. 2C). The penetration cysts cling well to the Corophium surface, on which they can persist for at least 5 days after the cercariae have left them (pers. obs.).

The fusiform shaped penetration cysts (Fig. 2D) have an average length and width ( \pm $\mathrm{SD}, N=50)$ of $62.3 \pm 2.04 \mu \mathrm{m}$ and $45.9 \pm 2.14 \mu \mathrm{m}$ respectively. In some of the empty cysts the penetration hole is still visible, having a more or less circular shape with an average diameter $( \pm \mathrm{SD})$ of $11.0 \pm 0.80 \mu \mathrm{m}(N=6)$. In all observed cases the penetration 
hole is situated on the longitudinal axis, but displaced to one pole of the cyst with respect to the transverse axis.

The infectivity of $M$. claviformis was not restricted to any particular part of the Corophium. Empty penetration cysts, with penetration holes, were found all over the body and on all appendages, and even in their most distal parts. However, a clear parasite preference for appendages over body segments appeared from the quantification of penetration cysts, as they almost exclusively (92\% of total) were found on the appendages. The major part (97\%) of the new metacercarial infections was found in the body cavity.

In both Corophium species a red substance, probably melanin, clotted around the penetration hole. In a few cases newly penetrated cercariae were caught in this substance (Fig. 2E) in which case they gradually detoriated (only the stylet was left in some cases). This phenomenon was observed in both Corophium species and in various appendages. Corophium that elicited this immune response did not escape infestation, as they all carried well-developed new infections as those shown in Fig. 2F.

\subsection{Mortality and infection}

Infection with $M$. claviformis caused increased mortality within the experimental population of $C$. volutator but not within $C$. arenarium (Fig. 3). This differential effect

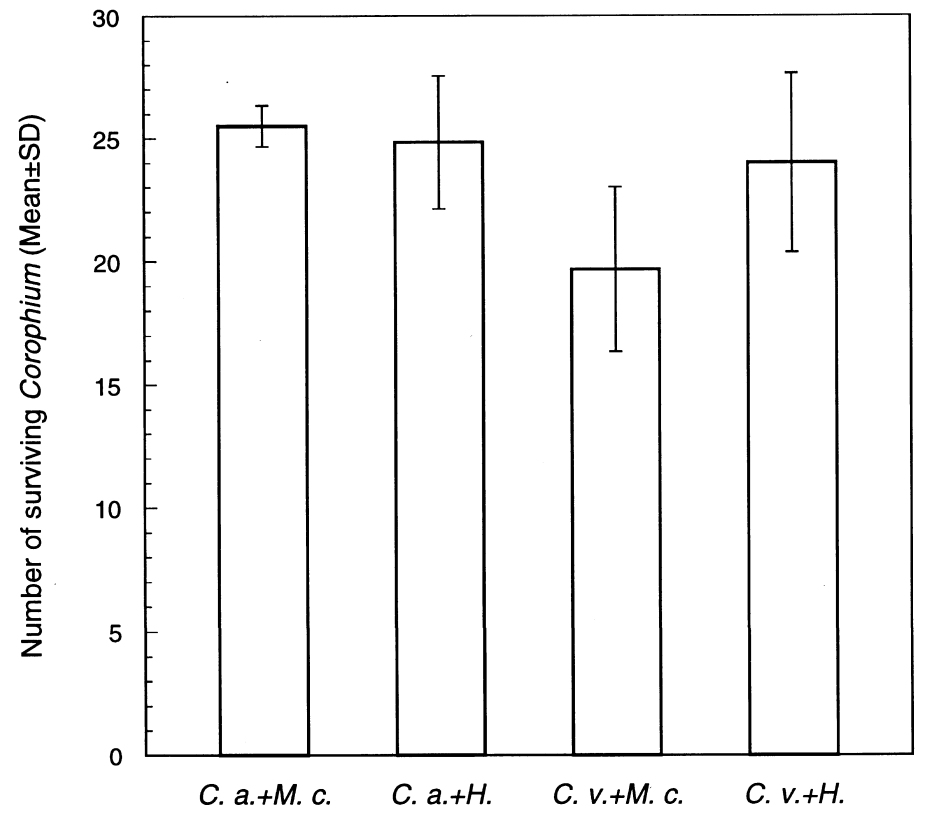

Fig. 3. Mean number of surviving Corophium specimens. The survival of $C$. volutator treated with $M$. claviformis was significantly different from all other groups (one-way ANOVA, $P<0.01$; LSD a posteriori tests: $P<0.05)$. No other significant differences exist between groups. $C$. $a .=C$. arenarium, $C$. $v .=C$. volutator, M. c. = M. claviformis, H. = Himasthla. 
Table 1

Two-way ANOVA evaluating the effect of exposure to M. claviformis on the survival of C. volutator and $C$. arenarium

\begin{tabular}{lclll}
\hline Source of variation & df & MS & $F$ & $P$ \\
\hline Species & 1 & 66.67 & 8.25 & 0.009 \\
Treatment & 1 & 20.17 & 2.49 & 0.130 \\
Two-way interaction & 1 & 37.50 & 4.64 & 0.044 \\
Within cells & 20 & 8.08 & & \\
\hline
\end{tabular}

of the parasite is supported by a significant interaction term in the two-way ANOVA (Table 1). A posteriori analysis revealed that the survival of $C$. volutator subjected to $M$. claviformis was significantly lower than for any other group (Fig. 3, legend). The dead individuals did not deviate from their surviving conspecifics concerning size, metacercarial pre-load (Mann-Whitney $\mathrm{U}$ tests, $P>0.05$ ) and sex ratio (Chi-square tests with Yate's correction, $P>0.05)$.

Descriptive statistics for experimentally induced metacercarial infections of Corophium are presented in Table 2 . The dead $C$. volutator specimens contained more new metacercariae than their live counterparts (Mann-Whitney $\mathrm{U}$ test, $P<0.001$ ), whereas no significant difference in infection level was found between dead and live $C$. arenarium (Mann-Whitney $\mathrm{U}$ test, $P>0.05$ ). Among the dead individuals, $C$. volutator was more infected than $C$. arenarium (one-way ANOVA on $\ln (x+1)$ transformed data, $P<0.05)$.

In both species, dead specimens carried more penetration cysts than those living at the end of the experiment (Mann-Whitney $\mathrm{U}$ tests, $P<0.05$ and $P<0.01$ for $C$. arenarium and $C$. volutator respectively).

Statistical analyses between infection intensities of dead and live Corophium within each species have been performed using the Mann-Whitney $U$ test, despite the lack of statistically independent data. Due to the earlier removal of dead individuals from the experimental system, they should intuitively hold fewer new infections and penetration cysts compared to individuals experiencing longer parasite exposure. In addition, the intensity of infections and penetration cysts of the Corophium that died during the experiment represents conservative estimates due to the very rapid disintegration of

Table 2

Descriptive data on new metacercarial infections within the body cavity of Corophium volutator $(C$. v.) and Corophium arenarium (C. a.). Dead specimens were removed from the aquaria during the experiment, live ones preserved at its termination. The $k$ parameter from the fitted negative binomial distribution only figures for live specimens

\begin{tabular}{|c|c|c|c|c|c|c|c|}
\hline $\begin{array}{l}\text { Species and } \\
\text { status }\end{array}$ & $\begin{array}{l}\text { Mean } \\
\text { intensity } \pm s d\end{array}$ & Range & Median & $\begin{array}{l}\text { Prevalence } \\
(\%)\end{array}$ & $N$ & $S^{2} /$ mean & $k$ \\
\hline C. $a$. alive & $10.9 \pm 6.92$ & $0-34$ & 10 & 99 & 152 & 4.39 & 3.1 \\
\hline C. v. alive & $12.4 \pm 10.02$ & $1-66$ & 10 & 100 & 119 & 8.11 & 2.3 \\
\hline C. $a$. dead & $12.4 \pm 6.55$ & $2-22$ & 13 & 100 & 8 & 3.46 & - \\
\hline C. v. dead & $22.2 \pm 11.36$ & $11-52$ & 20 & 100 & 17 & 5.80 & - \\
\hline
\end{tabular}


internal structures and limbs of a decaying Corophium (pers. obs.). If dead individuals, contrary to the expectations based on these considerations, should hold a higher level of infestation, these circumstances should compensate for the lack of statistically independent data.

Due to lack of detailed knowledge regarding species specific growth rates and hence the rate of ecdysis, the use of penetration cysts in comparative analyses between species is inexpedient. Their use is therefore restricted to intraspecific comparisons of mortality and to a discussion regarding the cause of death.

\subsection{Intensity and distribution of infections}

Considering only survived individuals, no difference in the intensity of new infections between the two Corophium species was found (one-way ANOVA on $\ln (x+1)$ transformed data, $P>0.05$ ). Infection intensity did not covary with Corophium length (probably due to the narrow size distribution selected) or with pre-experimental infection level.

The mean load $( \pm \mathrm{SD})$ of pre-experimental metacercariae of $C$. volutator $(3.0 \pm 3.16$, $N=139)$ was significantly higher than for $C$. arenarium $(0.6 \pm 1.05, N=163)$ (MannWhitney U test, $P<0.001$ ). Besides $M$. claviformis, another microphallid trematode, Maritrema subdolum, was present in our material as in situ infestations, the latter, however, only comprising $20 \%$ of the encountered metacercariae.

The variance-mean ratios, being above unity, indicated a contagious distribution of new infections in both Corophium species. The distribution of new infections in the two species is presented in Fig. 4, along with expected frequencies from a theoretical negative binomial model. The parasite loads of the individuals that died during the experiment are included, although these specimens have been omitted from the calculation of expected frequencies. No significant discrepancy between the observed data of new infections and those expected from the negative binomial model was found (Chi-square tests, $P>0.05$ ). The variance-mean ratio as well as the $k$ parameter from the negative binomial model indicated a greater overdispersion within $C$. volutator (Table 2). The two observed frequency distributions were significantly different (Kolmogorov-Smirnov test, $P<0.01$ ).

\subsection{Visual observations}

Analyses of surface activity are restricted to recordings from the start and end of the experiment where the exact number of living animals is known (8 and $22 \%$ of $C$. arenarium and $C$. volutator respectively, were never recovered). Nevertheless, counts from all dates with replicates pooled are presented in Fig. 5. Two-way ANOVA revealed no effect of either species or treatment at day 1 . At day 11, however, a significant effect of species emerged $(P<0.01)$ caused by the elevated surface activity of $C$. volutator.

\subsection{Post-experimental cercariae shedding}

All Hydrobia batches exhibited shedding of cercariae in a post-experimental check in 


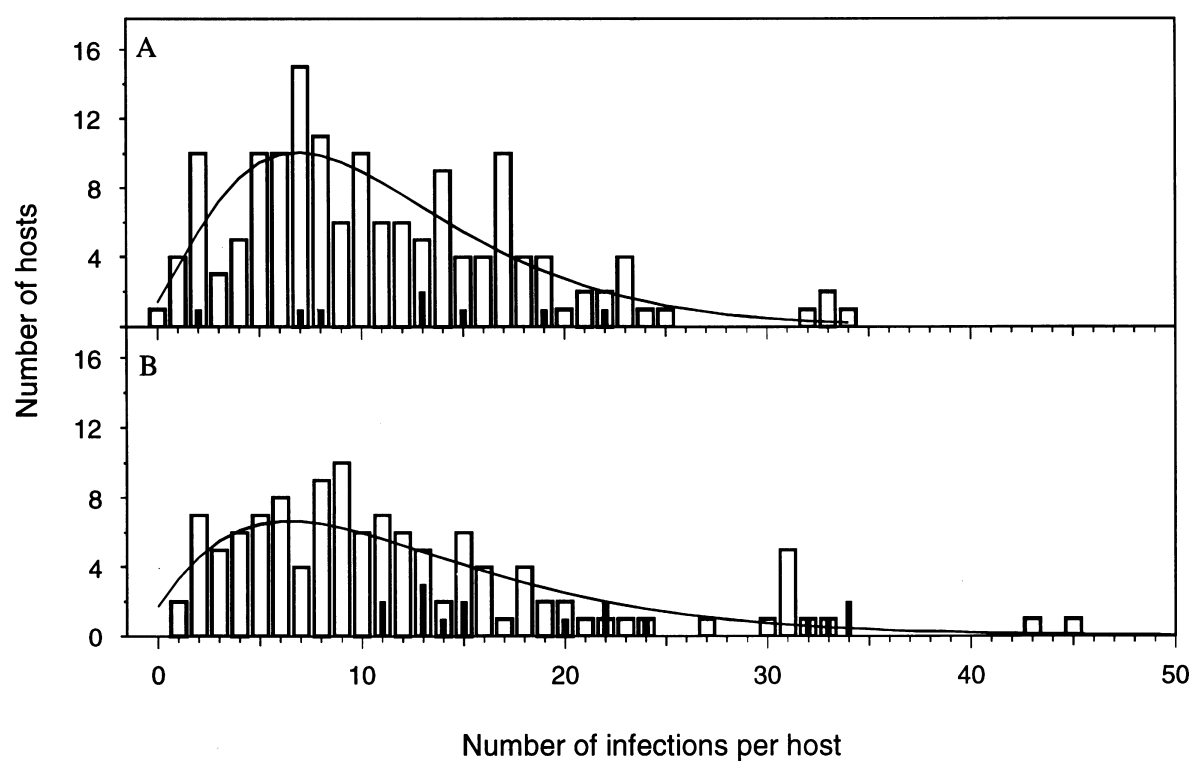

Fig. 4. Histogram of infections in live (open bars) and dead (closed narrow bars) Corophium specimens. (A): New infections in $C$. arenarium $N=152 / 8$; (B): New infections in $C$. volutator. $N=119 / 17$. One live and one dead individual carrying 66 and 52 infections respectively are omitted. The dead individuals are not included in the calculation of expected frequencies according to the negative binomial distribution, visualised as the superimposed curves.

renewed sea water, but not in vast numbers (range: 6-69, duration $2 \mathrm{~h}$ ). Many of the snails only emerged from their shells after $20 \mathrm{~min}$. Four snails infected with $M$. claviformis died during the experiment, each from different replicates.

\section{Discussion}

Transmission of infective larval stages seems to have taken place throughout the whole experiment, as all batches of snails shed cercariae post-experimentally. Many of the snails, however, only emerged from their shells after 20 min, which may be a sign of exhaustion, perhaps due to massive cercarial emergence during a short period of time (Ginetsinskaya, 1988). This may be a reflection of the prolonged high temperature during the experimental period and, in turn, elevated cercarial shedding rates.

$M$. claviformis showed no unequivocal host preferences in this system which suggests that infection can take place in both the burrows of Corophium and on the surface, otherwise a more pronounced difference in infection level between the two species would have been expected due to the difference in surface activity observed. $C$. arenarium was less surface active than $C$. volutator which more often leaves its burrow, as also observed in the field (Flach, 1996; pers. obs.). 


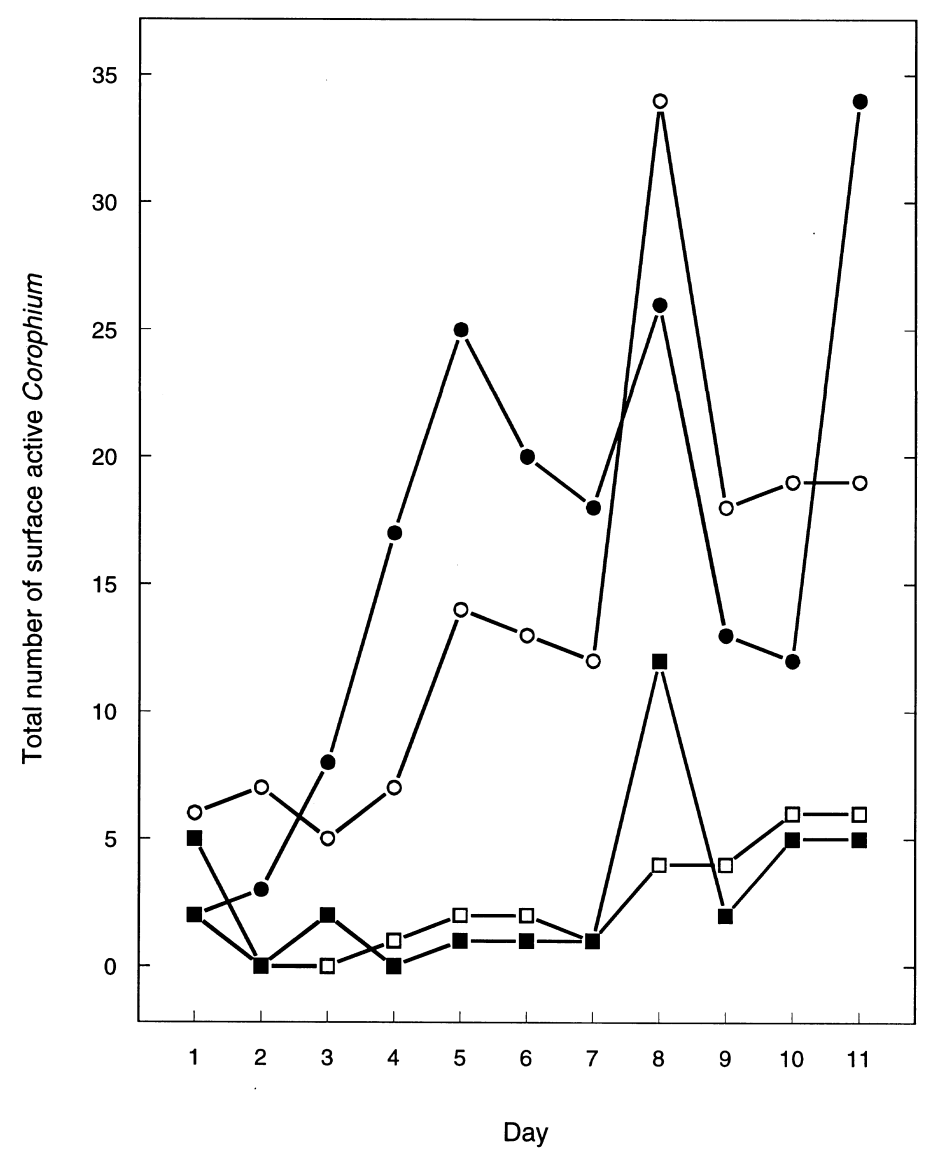

Fig. 5. Total number of surface active Corophium across replicates. $(\square / \mathbf{\square})$ C. arenarium, $(\bigcirc / \bigcirc) C$. volutator. Open markers, $M$. claviformis treatments; closed markers, control. Number of live specimens in each group for day 1 and 11 respectively is: $(\square)=179 / 153,(\boldsymbol{\square})=178 / 149,(\bigcirc)=180 / 118,(\boldsymbol{O})=180 / 144$.

However, the distribution of parasites within $C$. volutator was more overdispersed $(k$ smaller, variance-mean ratio larger) than within $C$. arenarium.

This is interesting as it is generally accepted that if two populations are suffering from intensity dependent parasite induced mortality, the most affected population is expected to show a lower degree of overdispersion (Anderson and Gordon, 1982; Esch and Fernández, 1993; Thomas et al., 1995a). Quite the opposite picture emerged here, suggesting a higher parasite accumulation within the competitively superior species $C$. volutator, perhaps being responsible for this species' lower survival rate.

The higher mortality rate observed within $C$. volutator could also be argued to be a result of the significantly higher pre-load of this species with respect to pre-experimental trematode infections. This, however, is an insufficient explanation as there were no significant differences in metacercarial pre-load between dead and live Corophium in either species. Instead other species characteristics are suggested to be of some influence. C. volutator has the highest reproductive output of the two species (Fish and 
Mills, 1979; Jensen, 1996), and as a part of its life-history strategy it probably allocates less energy to maintenance functions. This could render it more vulnerable to cercarial invasion than $C$. arenarium.

Other species characteristics such as behaviour, however, may also interfere with the pathogenicity of invading cercariae. Jensen (1996) found species specific differences between the two Corophium species with respect to the distribution of penetration cysts. On the more surface active $C$. volutator, these structures were more evenly distributed on the different body limbs, whereas they were confined to the anterior limbs on $C$. arenarium. Physical damage on the Corophium cuticle, including penetration cysts with holes, elicits an intense response with a heavy accumulation and clotting of blood cells ultimately ending up in melanisation of the damaged site. The presence of many such heavily melanized sites may inhibit the functional ability of the body part in question or reduce the flow of haemolymph (see also Mouritsen and Jensen, 1997). If infection through the anterior limbs is less detrimental to a Corophium than infection through mid or posterior limbs, this may contribute to their differential survival when exposed to $M$. claviformis.

Nevertheless, the physical explanation for the death of highly infected Corophium specimens remains largely unknown, but could be coupled to the level and flow of haemolymph or related to osmotic problems. Furthermore, the efficiency of a crustacean immune defence is proportional to the amount of blood cells (Poppe, 1990). Therefore multiinfections with penetrating trematodes may to some extent reduce the efficiency of the Corophium immune system either due to loss of haemolymph or due to heavy utilization of defence cells in repairing penetration sites. Such interference with the circulatory system and perhaps osmoregulation may further render highly infected Corophium specimens more vulnerable to otherwise sublethal stress factors.

Although mortality depends on intensity of new infections, crude parasite intensity did not explain all our observations as many individuals survived infections of a magnitude comparable to those who died. Furthermore, mortality was independent of pre-experimental infestation load, indicating that a steady accumulation of metacercariae does not necessarily cause increased mortality. A possible explanation for these inconsistencies is variation in individual vulnerability, but the actual cause of mortality may instead be more dependent on the relationship between time and infection than on crude parasite intensity. In support of this theory, dead individuals of both species possessed a significantly higher number of penetration cysts than the surviving ones, and we suggest that mortality is due to severe multiple infection during a short period of time, perhaps through a single burst of cercariae.

In clarifying the actual cause of Corophium death further, the use of parasites with and without production of penetration cysts could be of some help in forthcoming experiments. Preliminary results (unpub. data) indicate that the survival of $C$. volutator exposed to $M$. subdolum, which has not been observed to produce a penetration cyst, followed by immediate transfer to sea water of reduced salinity $(10 \%$ ), was lower than for controls. In a similar experiment using the penetration cyst forming $M$. claviformis, no effect of parasite exposure followed by transfer to lower salinities was elicited on the survival of $C$. volutator.

The apparent difference between the two parasite species in these short term experiments (less than $12 \mathrm{~h}$ of parasite exposure) was also observed when the present 11 
day experiment was compared to an experiment conducted with M. subdolum (Mouritsen and Jensen, 1997). In this experiment, an additive mortality of approx. 56\% was experienced for $C$. volutator whereas for the same temperature in the present 11 day experiment it was only approx. 19\%. Furthermore, this experiment showed a marginally significant parasite induced increase in the surface activity of $C$. volutator, a result we could not reproduce in the present experiment using M. claviformis. Alltogether these findings could indicate that the penetration cysts of $M$. claviformis gives rise to less detrimental effects on the Corophium host.

Penetration cysts are widespread among digenetic trematodes of the family Microphallidae (Burns, 1961; Hall and Groves, 1963; Deblock and Rosé, 1965; Helluy, 1982; Heard and Overstreet, 1983; Ginetsinskaya, 1988), but have to our knowledge never previously been described from $M$. claviformis. For a more thorough discussion of these structures and their functional purpose cf. Jensen (1996).

By affecting primarily $C$. volutator and thus perhaps compensating for this species' more superior competitive ability, $M$. claviformis could represent a "keystone parasite" in the dynamics of the two Corophium species. Although such parasite mediated coexistence of potential competitors has been predicted as a potentially important type of interaction in the field (Price et al., 1986), it has only been reported in a few cases (Schall, 1992; Scott and Dobson, 1989; Thomas et al., 1995a and references therein). Sensu Minchella and Scott (1991) a non-specific parasite, parasitising related species in a frequency dependent manner, or a more specific parasite with preference for the competitively superior species, should lead to increased species diversity.

However, the structuring potential of $M$. claviformis outside this experimental system must be evaluated in relation to other structuring factors of the population dynamics such as predation, inter- and intraspecific competition and abiotic stress factors in order to establish its importance in the field. In this evaluation the existence of more subtle effects of parasites on their hosts should be considered, as mortality is only the ultimate effect of parasitism. A wide range of sub-lethal effects of parasites on their hosts has been reported such as castration, reduced fecundity and behavioural changes facilitating trophic transmission of the parasite (Reinhard, 1956; Barnard and Behnke, 1990; Huxham et al., 1993; Schwartz and Cameron, 1993; Mouritsen and Jensen, 1994; Thomas et al., 1995b).

Furthermore, the dynamic properties of this host-parasite system have to be recognised when stating the influence of parasites on host dynamics. Not only do natural populations of Corophium show wide fluctuations in time and space - the prevalence of the parasites, which ultimately rely on the bi-annual arrival of migrating birds, also varies considerably in time (Mouritsen et al., in press). Consequently, the impact of microphallid parasites on natural populations of Corophium may be expected to represent a continuum ranging from dramatic epizootic events (Jensen and Mouritsen, 1992) through periods of less dramatic population dynamic consequenses via regulation in the sense of e.g. Anderson (1991).

\section{Acknowledgements}

We are grateful to D. Strøyberg for editing the text, to T. Greve for valuable 
comments on earlier versions of the manuscript, to Dr. P.U Middelfart for help with the figures and to A.H. Jensen for help in the laboratory. This work was financially supported by the Carlsberg Foundation (grant to K.T. Jensen and K.N. Mouritsen).

\section{References}

Anderson, R.M., Gordon, D.M., 1982. Processes influencing the distribution of parasite numbers within host populations with special emphasis on parasite-induced host mortalities. Parasitology 85, 373-398.

Anderson, R.M., 1991. Populations and infectious diseases: ecology or epidemiology? J. Anim. Ecol. 60, $1-50$.

Barnard, C.J., Behnke, J.M. (Eds.), 1990. Parasitism and Host Behaviour. Taylor and Francis, London.

Beukema, J.J., Flach, E.C., 1995. Factors controlling the upper and lower limits of the intertidal distribution of two Corophium species in the Wadden Sea. Mar. Ecol. Prog. Ser. 125, 117-126.

Bick, A., 1994. Corophium volutator (Corophiidae: Amphipoda) as an intermediate host of larval digenea - an ecological analysis in a coastal region of the southern Baltic. Ophelia 40, 27-36.

Burns, W.C., 1961. Penetration and development of Allassogonoporus vespertilionis and Acanthatrium oregonense (Trematodea: Lecithodendriidae) cercariae in caddis fly larvae. J. Parasitol. 47, 927-932.

Curtis, L.A., Hubbard, K.M., 1990. Trematode infections in a gastropod host misrepresented by observing shed cercariae. J. Exp. Mar. Biol. Ecol. 143, 131-137.

Deblock, S., 1980. Inventaire des trematodes larvaires parasites des mollusques Hydrobia (Prosobranchia) des côtes de France. Parassitologia 22, 1-105.

Deblock, S., Rosé, F., 1965. Contribution a l'étude des Microphallidae Travassos, 1920 (Trematoda) des oiseaux de France. XI. - Identification de la cercaire de Microphallus claviformis (Brandes, 1888). Bull. Soc. Zool. Fr. 90, 299-314.

Dobson, A.P., Hudson, P.J., 1986. Parasites, disease and the structure of ecological communities. Trends in Ecol. Evol. 1, 11-15.

Esch, G.W., Fernández, J.C., 1993. A Functional Biology of Parasitism: Ecological and Evolutionary Implications. Chapman and Hall, London.

Fish, J.D., Mills, A., 1979. The reproductive biology of Corophium volutator and Corophium arenarium (Crustacea: Amphipoda). J. Mar. Biol. Ass. U.K. 59, 355-368.

Flach, E.C., 1993. The distribution of the amphipod Corophium arenarium in the Dutch Wadden Sea: relationships with sediment composition and the presence of cockles and lugworms. Neth. J. Sea Res. 31, 281-290.

Flach, E.C., 1996. Distribution of Corophium at different scales. Senckenbergiana maritima 27, 119-127.

Ginetsinskaya, T.A., 1988. Trematodes, Their Life Cycles, Biology and Evolution (Dr. I. Kohli, Trans.). Amerind Publishing Co. Pvt., New Delhi (original work published 1968).

Hall, J.E., Groves, A.E., 1963. Virgulate Xiphidiocercariae from Nitocris dilatatus Conrad. J. Parasitol. 49, 249-263.

Heard, R.W., Overstreet, R.M., 1983. Taxonomy and life histories of two North American species of "Carneophallus" (= Microphallus) (Digenea: Microphallidae). Proc. Helmint. Soc. Wash. 50, 170-174.

Helluy, S., 1982. Relations hotes-parasite du Trématode Microphallus papillorobustus (Rankin, 1940). I. Pénétration des cercaires et rapports des métacercaires avec le tissu nerveux des Gammarus, hôtes intermédiaires. Ann. Parasitol. (Paris) 57, 263-270.

Huxham, M., Raffaelli, D., Pike, A., 1993. The influence of Cryptocotyle lingua (Digenea: Platyhelminthes) infections on the survival and fecundity of Littorina littorea (Gastropoda: Prosobranchia); an ecological approach. J. Exp. Mar. Biol. Ecol. 168, 223-238.

Jensen, T., 1996. The influence of microphallid trematodes on the host organisms Corophium volutator and $C$. arenarium. M.Sc. thesis, Institute of Biology, department of Ecology and Genetics, University of Aarhus, Denmark.

Jensen, K.T., Kristensen, L.D., 1990. A field experiment on competition between Corophium volutator (Pallas) and Corophium arenarium Crawford (Crustacea: Amphipoda): Effects on survival, reproduction and recruitment. J. Exp. Mar. Biol. Ecol. 137, 1-24. 
Jensen, K.T., Mouritsen, K.N., 1992. Mass mortality in two common soft-bottom invertebrates, Hydrobia ulvae and Corophium volutator - the possible role of trematodes. Helgol. Meeresunters. 46, 329-339.

Lauckner, G., 1987. Effects of parasites on juvenile Wadden Sea invertebrates. In: Tougaard, S., Asbirk, S. (Eds.), Proceedings of The 5th International Wadden Sea Symposium. The National Forest and Nature Agency and The Museum of Fishery and Shipping, Esbjerg, Denmark, pp. 103-121.

Lincoln, R.J., 1979. British Marine Amphipoda: Gammaridea. British Museum (Natural History), London.

Minchella, D.J., Scott, M.E., 1991. Parasitism: A cryptic determinant of animal community structure. Trends Ecol. Evol. 6, 250-253.

Mouritsen, K.N., Jensen, K.T., 1994. The enigma of gigantism: effect of larval trematodes on growth, fecundity, egestion and locomotion in Hydrobia ulvae (Pennant) (Gastropoda:Prosobranchia). J. Exp. Mar. Biol. Ecol. 181, 53-66.

Mouritsen, K.N., Jensen, K.T., 1997. Parasite transmission between soft bottom invertebrates: temperature mediated infection rates and mortality in Corophium. Mar. Ecol. Prog. Ser. 151, 123-134.

Mouritsen K.N., Jensen, T., Jensen K.T., in press. Parasites on an intertidal Coropium-bed: factors determining the phenology of microphallid trematodes in the intermediate host populations of the mud-snail Hydrobia ulvae and the amphipod Corophium volutator. Hydrobiologia.

Muus, B., 1967. The fauna of Danish estuaries and lagoons. Distribution and ecology of dominating species in the shallow reaches of the mesohaline zone. Meddelelser fra kommisionen for Danmarks Fiskeri-og Havunders $\varnothing$ gelser. Serie: Fiskeri 5, 1-316.

Olafsson, E.B., Persson, L.E., 1986. The interaction between Nereis diversicolor O.F. Mueller and Corophium volutator Pallas as a structuring force in a shallow brackish sediment. J. Exp. Mar. Biol. Ecol. 103, $103-117$.

Poppe, T.T., 1990. Fiskehelse: Sykdommer, Behandling, Forebygning. John Grieg, Bergen.

Price, P.W., Westoby, M., Rice, B. et al., 1986. Parasite mediation in ecological interactions. Ann. Rev. Ecol. Syst. 17, 487-505.

Reinhard, E.G., 1956. Parasitological reviews. Parasitic castration of Crustacea. Parasitology 5, $79-107$.

Reise, K., 1978. Experiments on epibenthic predation in the Wadden Sea. Helgol. Wiss. Meeresunters. 31, 55-101.

Schall, J.J., 1992. Parasite-mediated competition in Anolis lizards. Oecologia 92, 58-64.

Schwartz, S.S., Cameron, G.N., 1993. How do parasites cost their hosts? Preliminary answers from trematodes and Daphnia obtusa. Limnol. Oceanogr. 38, 602-612.

Scott, M.E., Dobson, A., 1989. The role of parasites in regulating host abundance. Parasitol. Today 5, $176-183$.

Snedecor, G., Cochran, W.G., 1989. Statistical Methods. Iowa State University Press, Ames, Iowa.

Sousa, W.P., 1991. Can models of soft-sediment community structure be complete without parasites?. Am. Zool. 31, 821-830.

Thomas, F., Renaud, F., Rousset, F., Cezilly, F., De Meeûs, T., 1995. Differential mortality of two closely related host species induced by one parasite. Proceedings of the Royal Society of London, series B. Biol. Sci. 260, 349-352.

Thomas, F., Lambert, A., De Meeûs, T., Cézilly, F., Renaud, F., 1995. Influence of Microphallus hoffmanni (Trematoda, Microphallidae) on the survival, sexual selection, and fecundity of Gammarus aequicauda (Amphipoda). Can. J. Zool. 73, 1634-1639.

Watkin, E.E., 1941. The yearly life cycle of the Amphipod, Corophium volutator. J. Anim. Ecol. 10, 77-93. 